Whitewood, Peter (2020) The

International Situation: Fear of Invasion and Growing

Authoritarianism. In: Douds, Lara, Harris, James and Whitewood, Peter, (eds.) The Fate of the Bolshevik Revolution: Illiberal Liberation, 1917-1941. Library of Modern Russia . London, Bloomsbury, pp. 173-186

Downloaded from: http://ray.yorksj.ac.uk/id/eprint/3732/

The version presented here may differ from the published version or version of record. If you intend to cite from the work you are advised to consult the publisher's version: https://www.bloomsbury.com/us/the-fate-of-the-bolshevik-revolution-9781350117907/

Research at York St John (RaY) is an institutional repository. It supports the principles of open access by making the research outputs of the University available in digital form. Copyright of the items stored in RaY reside with the authors and/or other copyright owners. Users may access full text items free of charge, and may download a copy for private study or non-commercial research. For further reuse terms, see licence terms governing individual outputs. Institutional Repository Policy Statement

\title{
RaY
}

Research at the University of York St John

For more information please contact RaY at ray@yorksj.ac.uk 


\section{The International Situation: Fear of Invasion and Growing Authoritarianism}

Peter Whitewood

For Vladimir Lenin and the Bolsheviks, the primary function of their revolution in 1917 was to spark further uprisings in the more advanced countries of Western Europe. This would bring forth worldwide revolution and usher in world communism. For them, this was the only role that a revolution in a struggling empire with a large peasant majority, an underdeveloped working class and backwards-industrial base, could possibly play. In fact the revolution would not survive without spreading further afield. As a result, when European revolution failed to ignite, the Bolsheviks faced a serious security dilemma: Russia was surrounded by countries with governments hostile to communism. Civil war that erupted in 1918 only underlined the precarious position of the Soviet government. Western capitalist powers Britain, France and the United States - all gave financial and material support to the Bolsheviks’ enemies, first in an effort to keep the eastern front open against Germany and then in an effort to snuff out the Soviet government. As far as Lenin was concerned, this was evidence of capitalist encirclement.

Bolshevik victory in the civil war did not provide a sense of security. Even though the immediate danger to the revolution had been overcome, the Bolsheviks would never forget the assistance given to their enemies by capitalist powers. Moreover, the Bolsheviks were convinced that the capitalist world would never reconcile to their revolutionary state and would continue to seek its destruction. All of this heightened the dangers posed by the outside world and there were serious consequences. Historians have recently given more attention to 
Bolshevik leaders' misperceptions of foreign threats and how this explains their use of political violence. ${ }^{1}$ Yet less attention has been given to how Bolshevik perceptions of the international situation shaped the dictatorship itself in the 1920s. ${ }^{2}$ This chapter will show how a perpetual fear of foreign intervention encouraged Bolshevik leaders to retreat from the democratic impulses of 1917 and from the workers democracy promised at the outset of the revolution. The Bolshevik Party was instead pushed further towards authoritarian practices, accelerating the consolidation of a one-party vanguard-led state that placed growing limits on intraparty discussion. Perceived security concerns shared across the Soviet elite were a powerful force in the weakening of democratic practices in the 1920s.

In examining how the Bolsheviks understood the outside world and the impact this had on democratic practices, this chapter will concentrate on the perceived threat of war between Poland and the Soviet Union. This was the most common foreign policy preoccupation for the Bolsheviks in the 1920s. Indeed, having experienced stunning defeat against the Poles at the Battle of Warsaw in August 1920 - a clash that brought the Soviet-Polish War to a close the Bolsheviks fully expected renewed war against Poland, supported by powerful capitalist states, in the years after.

\section{Fears of Renewed War, 1921-3}

After narrowly avoiding defeat by the White Armies and interventionist foreign powers at the height of the civil war, the Bolsheviks found themselves in more secure circumstances in the early 1920s. Appraising the outside world in February 1921, Lenin proclaimed that the 
'greatest danger point' to the revolution had passed. He saw major conflict in the near future as a risky undertaking for capitalist powers facing economic crises and rising revolutionary movements at home. Yet Lenin warned against complacency: the external threat had not been eliminated. ${ }^{3}$ Open war against the capitalist world was unavoidable and until then, the revolution - isolated in the world - would be forced to exist under conditions of capitalist encirclement.

It was in this context that the Bolsheviks judged newly reconstituted Poland as the most dangerous international threat to the revolution. The Soviet-Polish War officially ended when the Treaty of Riga was signed on 18 March 1921, but this was nothing more than an uneasy compromise (with the majority of treaty conditions ultimately going unfulfilled). ${ }^{4}$ For this reason, failure to usher in peaceful relations in 1921 has been described as the starting point of a cold war between the two countries. ${ }^{5}$ Indeed, formal peace did little to ease Bolshevik concerns that the Entente would once again push Poland into war when the time was right. Lenin made precisely this point prior to the signing of the treaty in early 1921. Even though he saw war as a risky undertaking for the revolution's enemies, Lenin proclaimed that foreign capitalists were 'spending millions and millions to organise another invasion in spring.' Yet without the assistance of a pliable state bordering Soviet territory he argued, these efforts would come to nothing. It was Poland (and Romania) - sold to the capitalists 'lock, stock, and barrel' and vulnerable to manipulation - who might 'rush headlong into the craziest adventures. ${ }^{6}$ For Lenin, despite the formal end of hostilities against Poland, the international situation remained precarious. 
Lenin was not alone in this reading of the outside world. The Soviet political police estimated that a new military attack might come in spring or summer 1921 and pointed to extensive activity of Polish intelligence agents in Ukraine. ${ }^{7}$ Similarly, Bolshevik negotiators at the peace talks with Poland in 1921 could not discount a rapid resumption of hostilities. Soviet representative Adolf Ioffe, for instance, suggested to People’s Commissar for Finance, Nikolai Krestinskii, that the Bolsheviks accept the Polish government's demands for gold as deliveries could be staggered over two or three years, staving off another invasion during this time. ${ }^{8}$ There were some moderate voices in the early 1920s. The People’s Commissariat of Foreign Affairs tended to report a more benign picture of the foreign threat in 1921. People’s Commissar Georgii Chicherin, for instance, received a stream of diplomatic reports describing consensus within the Polish government for quickly achieving a peace treaty, yet these equally stressed continuing international hostility towards Soviet Russia and concerted efforts spearheaded by the French to create a union of anti-Soviet border-states. ${ }^{9}$

It is clear that the Bolsheviks did not rule out another military clash against Poland after the Treaty of Riga and this soon shaped strategies for new international alliances. In October 1921, Maksim Litvinov, Deputy People’s Commissar for Foreign Affairs, recommended that the Bolsheviks arrange a defensive alliance with Germany because Poland was likely to remain a '“sword of Damocles” hanging over our heads.' (The Soviet foreign ministry would later warn of imminent war against Poland and Romania in early 1922.) ${ }^{10}$ Commissar for War, Leon Trotsky, in an order from the Revolutionary Military Council from November 1921, took aim at a shadowy military clique in Poland headed by Józef Piłsudski pushing for renewed war and stressed that the Red Army needed to be prepared for the worst. ${ }^{11}$ Yet as we have seen, Poland was regarded as the instrument of war; the Bolsheviks continued to see the British and French governments as the crucial backers. 
As had been true in the previous war against Poland, the Bolsheviks identified Ukraine as a weak spot in their defences and as a potential bridgehead in a future clash with the west. Consequently the western front, in comparison to other civil war fronts, was converted to peacetime military district status only in April $1924 .{ }^{12}$ Mikhail Tukhachevskii, famed commander of the 1920 Battle of Warsaw, returned to oversee the western front between January 1922 and March 1924. Moreover, banditry in Ukraine, coordinated by separatist leaders such as Symon Petliura (and given covert support by Polish intelligence) was at times interpreted by the Soviet political police as directed by Poland in advance of a military assault. ${ }^{13}$ The activity of bandits in the borderlands was a common source of complaint in Soviet notes to the Polish government and tied to the potential resumption of hostilities. ${ }^{14}$

Fears about imminent war were eased - or at least downplayed - by senior Bolsheviks at the Eleventh Party Congress held between March and April 1922. The congress recognised that Poland (and Romania) had represented direct threats in autumn 1921 but that peace had been ensured because of military preparations and effective diplomacy. ${ }^{15}$ Nevertheless, further intelligence about a military attack quickly filtered through to the leadership. Sergei Kamenev, commander in chief of the Red Army, reported to Iosif Stalin at the end of April that recent intelligence indicated that Poland and Romania were considering launching military action in late spring or early summer. According to Kamenev, a military meeting in Romania had been attended not only by the Polish military attaché but also by representatives of the French government, Petliura and the White General Petr Wrangel' ${ }^{16}$ This news was followed up two weeks later with a report from the political police's foreign department describing 'serious discussions' in Latvia about a possible conflict between Poland and 
Russia. ${ }^{17}$ Soviet intelligence reported over the coming months on French-Polish-Romania military cooperation, the movement of Polish troops to the borders of Ukraine and the possibility of a new attack if conditions were right to spark the internal collapse of the Bolshevik state. ${ }^{18}$ The French government was rightly presented in these materials as striving to create a unified Polish and Romanian military force for potential action in Russia and to be held in reserve against Germany. Soviet intelligence agents also accurately assessed Poland's inability to wage war independently. This was only possible with the assistance of powerful countries to bankroll a new conflict. For the party leadership, however, none of this made war any less inevitable in the future. ${ }^{19}$ By the end of 1922, rumours about war continued to circle when Mikhail Frunze, commander of the Ukrainian military district, received a report on 'lively' discussions in Polish military circles about war in the east and the supposed efforts by Petliura's bands to encourage Polish intervention. ${ }^{20}$ In early 1923, Soviet intelligence agents in Ukraine were tasked with obtaining Polish, Latvian and Estonian mobilisation plans. ${ }^{21}$

Fears about a new war were significantly heightened when international crisis erupted in Western Europe in 1923 after French and Belgian troops occupied the Ruhr industrial region in January following the failure of the German government to meet its reparations payments. Hyperinflation soon hit the Germany economy sparking a strike wave across German cities that culminated in the failed Hamburg insurrection in October. The Politburo threw its support behind the German Communist Party in the summer, envisaging another revolution. But with revolutionary optimism came fears of new war. For some Bolsheviks, a conflict with Poland was now more likely than ever. Until the collapse of the German uprising became clear in the autumn, the prospect of Polish military intervention to quash the insurrection was taken seriously (the Bolsheviks believed that the Polish government would never permit their country to be surrounded on both sides by revolutionary states). There was 
now serious talk in Bolshevik circles of using the Red Army to protect the nascent German revolution as the crisis matured. ${ }^{22}$ Trotsky in particular was determined to go to war if necessary, writing to Karl Radek at the outset of the crisis that the Bolsheviks could not stand aside if Poland attacked Germany. ${ }^{23}$ Grigorii Zinoviev, the most prominent supporter of the German communists, like Trotsky, wanted more resources committed to the army. ${ }^{24}$ At the Twelfth Party Congress in April 1923, Zinoviev proclaimed that the occupation of the Ruhr meant that war had in fact already arrived; it was merely war by other means. ${ }^{25}$

For this reason, during the course of 1923 Soviet military and GPU intelligence agents kept a close eye on potentially threatening troop movements and mobilisations. They reported that the French general staff believed that war with Germany would evolve into war against Russia and that military union with Poland was an essential part of French strategy towards Germany. ${ }^{26}$ Soviet intelligence tracked the movements of French marshal Ferdinand Foch and his efforts to forge a military alliance between France, Poland and other border states in the event of war with Russia. ${ }^{27}$ Alarmingly, Soviet intelligence from March noted that a majority within the Polish general staff now believed that another war should be launched against Russia to overthrow Soviet power and guarantee the Polish eastern border. Other reports noted the build up of Polish military supplies in border regions and on the right bank of the Vistula. ${ }^{28}$ GPU operatives on the ground in Ukraine recorded that Polish representatives were discussing war and the possibility of Polish troops being sent to Kiev. ${ }^{29}$ Soviet intelligence reported on the adaption of Polish railways to match those in Eastern Ukraine. ${ }^{30}$ The Red Army began to war-game possible conflicts, accepting that the international situation in Western and Central Europe made armed conflict between the Soviet Union and Poland, Romania and White organisations, inevitable. ${ }^{31}$ 
That the Bolsheviks took the threat of war seriously in 1923 can also be seen in the secret military preparations undertaken during the crisis. The Red Army in general terms was in no condition to fight in a major conflict, something that had been laid bare in a report on Soviet defences in May 1923. This judged the Red Army as clearly lagging behind Polish Army and called for its urgent strengthening. ${ }^{32}$ Other weaknesses in Soviet defences had also been highlighted during the year. Head of the GPU, Feliks Dzerzhinskii, described problems in Soviet transport infrastructure and the inability to efficiently move troops. He concluded that Poland would be able to carry out a successful short strike towards Kiev. ${ }^{33}$ Concrete plans for war were thus put into motion, particularly as the crisis in Germany reached a peak. ${ }^{34}$ On 18 September 1923, the Politburo ordered a strengthening of Red Army units on the western front, in the Ukrainian military district and in air defence. ${ }^{35}$ The following day, the Revolutionary Military Council ordered an increase in the number of political officers on the western front. ${ }^{36}$ In October, student communists were called up as political officers on the western front and demobilised Red Army men returned to the ranks. ${ }^{37}$ In November, Soviet industry officials in Ukraine began to secretly prepare for the evacuation of enterprises, factories and workers in the border region in case war suddenly erupted. ${ }^{38}$ Rumours of war were now widespread. ${ }^{39}$ The Ukrainian GPU recorded lively conversations about forthcoming war among Poles. ${ }^{40}$ Polish intelligence agents likewise reported that Kiev was alive with signs of preparation for new conflict. ${ }^{41}$

Despite growing anxiety about a clash with Poland and the raft of military preparations, war never materialised. The Hamburg uprising fizzled out almost as soon as it began, bringing the wider crisis to an end. However, what matters is how the Bolshevik leaders had misperceived 
the threat of war in 1923. There were undoubtedly certain circles in Poland - particularly within the military and intelligence services - pushing for war in 1923. However, the centreright National Democrats dominated Polish politics during that year. Their priority was closer economic relations with Russia, not launching another invasion. The National Democrats disagreed entirely with the aggressive approach championed by Piłsudski and his supporters. In fact, Piłsudski had resigned as chief of the general staff in May and his allies were subsequently ousted from government. The years 1923 to 1925 saw Polish policy towards Russia more firmly reoriented towards seeking trade agreements. Notably, the Polish government recognised the formation of Soviet Union in December $1923 .{ }^{42}$ In short, voices clamouring for war near the Polish government were weakened at the very moment that the Bolsheviks took the threat of war most seriously. The 1923 war scare reveals how precariously the Bolsheviks viewed their position in the world and the degree to which they misperceived the nature of foreign threats.

\section{Capitalist Encirclement and Dictatorship}

The international crisis of 1923 coincided with rising political opposition inside the Bolshevik Party. At the height of the crisis in October, Trotsky and the Left Opposition launched a scathing attack on the party majority, criticising it - and Stalin in particular - of presiding over the bureaucratisation of party life, the creation of a secretarial hierarchy and for placing limits on internal discussion and intraparty criticism. The response from the party majority to this challenge was shaped by a number of priorities, but it is clear that perceived threats of invasion and capitalist encirclement, unbroken since the end of the civil war, played important roles in the shutting down of Trotsky and his supporters. Lenin had already 
established this as a precedent. In early 1921, when tensions were running high about the resumption of hostilities against Poland, Lenin and the party majority faced criticism from minority political groups, the Workers’ Opposition and Democratic Centralists. Both criticised weak democratic practices, the growing bureaucracy and inadequate worker representation in senior party bodies. ${ }^{43}$ At the time Lenin responded that these problems could not be immediately remedied for a number of reasons, not least because workers lacked adequate experience of government, but also because the threatening international situation made dictatorship necessary. In an article published in Pravda in January 1921, Lenin argued:

The Entente capitalists will surely try to take advantage of our Party's malaise [political disputes] to mount another invasion [...] We need have no fear of this because we shall all unite as one man, without being afraid to admit the malaise, but recognising that it demands from all of us a greater discipline, tenacity and firmness at every post. ${ }^{44}$

In his opening speech to the Tenth Party Congress two months later - which approved the ban on factions in the party - Lenin proclaimed that past discussions and disputes had been an ‘amazing luxury' for a party shouldering such responsibilities and 'surrounded by mighty and powerful enemies uniting the whole capitalist world.' Lenin again argued that foreign powers were taking advantage of internal party disputes, with foreign presses spreading rumours of communist weaknesses. ${ }^{45}$ None of this is to say that the Bolsheviks' perception of international relations was the sole cause of the ban of factions. Yet it is clear that for Lenin at least, at a time when the country faced powerful enemies from within and without, the party needed to be more united than ever before. 
Lenin reiterated the necessity of dictatorship with similar justifications at the Third Congress of the Communist International held between June and July 1921: 'This dictatorship is essential as long as classes exist, as long as the bourgeoisie, overthrown in one country, intensifies tenfold its attacks on socialism on an international scale.’ Describing dictatorship as a 'state of intense war', Lenin argued that resistance from the working classes around the world was the only restraining force on the international bourgeoisie, though war could 'never be ruled out'. ${ }^{46}$ In this context, free political organisation could not be permitted. As Lenin explained to the oppositionist Gavriil Miasnikov in a letter from August 1921, this would simply give another weapon to the world bourgeoisie. ${ }^{47}$

Similar criticisms were aired at the Eleventh Party Congress in the following year. Here, senior Bolsheviks again cast calls for stronger democratic practices as impermissible in a dangerous international environment. Criticising Aleksander Shliapnikov, leader of the Workers' Opposition, Lenin argued against free political organisation and emphasised the threat of war as the primary danger:

I have indicated the three conditions under which it will be possible for us to hold on: first, that there shall be no intervention; second, that the financial crisis shall not be too severe; and third, that we shall make no political mistakes [...] Of course, even today the bourgeoisie may attempt another armed intervention, but they will find it much more difficult than before; it is much more difficult today than it was yesterday. To ensure ourselves the opportunity to learn we must make no political mistakes. We must waste no time playing with the unity of the Party, as Comrade Shlyapnikov is doing. ${ }^{48}$ 
Trotsky was likewise critical of opposition in the party at the congress and claimed that hostile states were turning this to their advantage: 'It is not an accident that the radio station of the Polish government sent extracts from comrade Miasnikov's pamphlet out to the whole world.' Trotsky also remarked that the writings of Aleksandra Kollontai, a figure closely associated with the Workers' Opposition, were being quoted abroad. ${ }^{49}$ The congress ultimately deemed the activity of the Workers' Opposition impermissible for several reasons: the continuing difficult economic circumstances, the presence of 'capitalist elements' in Russia, the spread of famine and the threat of invasion..$^{50}$

Similarly, in the year of Ruhr crisis and at the Twelfth Party Congress in April 1923, Lev Kamenev discussed the international position of the revolution and the question of party unity in his opening comments. He argued that enemies surrounded Soviet Russia on all sides and that unity in the party was necessary, adding that the Bolsheviks were in the position of the 'most shelled post' in the world proletarian revolution. ${ }^{51}$ Stalin framed his case for party unity in a way that he would repeat in later years. Arguing that the party had become too large to allow broad open discussion, he made a comparison to circumstances before the revolution. For Stalin, the Bolsheviks were in the same position as they had been in 1912 when surrounded by opponents; the difference now was that their 'enemies' were on an international scale. Moreover, Stalin claimed that there was no reason to doubt that preparatory work for a blockade or intervention was not taking place. For this reason, open discussion in the party could not be permitted, especially when this discussion concerned the most important questions: war and peace. Attacking the suggestion of allowing more liberal discussion in the party, Stalin added: 'We can’t talk about questions of war or peace on the 
streets $[\ldots]$ we need to remember that in an environment when we are surrounded by enemies, a sudden blow, or unexpected manoeuvre, decides everything. ${ }^{52}$

Consequently, when Trotsky and the Left Opposition moved to challenge the party majority more concertedly in October 1923, the threatening international situation was again emphasised as another reason why this was unacceptable. Most clearly, the resolution from the Joint Plenum of the Central Committee and Central Control Commission at the end of October 1923, which roundly condemned Trotsky and his supporters on the basis of their programme and behaviour, noted that 'we have already entered a period that can be called direct combat' and made reference to current events in Germany and the possibility of war against Poland. In this moment, the resolution stated, 'factional discussion' was prohibited. ${ }^{53}$ Sticking to his past views, Trotsky agreed that factionalism in the party was dangerous when war threatened (though by this time he had moderated his opinion on the immediate threat from Poland and insisted that relations had improved between the two countries). Important for Trotsky, however, was that his criticism of the majority should not be characterised as factionalism. Nevertheless, Trotsky had put himself in a difficult position by continuing to accept the premise that factionalism was dangerous when war threatened.

At the end of 1923 the party majority temporarily conceded to party-wide discussions on workers' democracy, but 'factionalism' was still ruled out. ${ }^{54}$ At the same time the everpresent threats of war and capitalist encirclement continued to raise questions about whether more robust party democracy and intraparty criticism were permissible. At the Thirteenth Party Conference in January 1924, Stalin made his views on the impossibility of party democracy in the context of possible war particularly clear: 
I have already said that there is another group of conditions, of an external nature, and in the absence of these democracy in the Party is impossible. I have in mind certain international conditions that would more or less ensure peace and peaceful development, without which democracy in the Party is inconceivable. In other words, if we are attacked and have to defend the country with arms in hand, there can be no question of democracy, for it will have to be suspended [...] What Trotsky offers is deeply mistaken; it runs counter to Bolshevik organisational principles and would lead to the inevitable disintegration of the party, to its softening, turning it from a single party into a federation of groups. In conditions of capitalist encirclement, we need not only a united, not only a skillful, but a party of real steel, capable of withstanding the onslaught of the enemies of the proletariat, capable of leading the workers to the final battle. ${ }^{55}$

That Lenin, Stalin, other senior Bolsheviks in the party majority, but also leading oppositionists like Trotsky, argued that political freedom was potentially dangerous when Soviet Russia existed under capitalist encirclement is not to argue that this was the sole consideration for the maintenance of a one-party dictatorship. However, as we have seen, the Bolsheviks saw the outside world in more dangerous terms than warranted and this understanding of international affairs in turn shaped attitudes towards whether democratic practices were permissible. From the Bolsheviks’ point of view, a unified and disciplined party dictatorship remained critical for survival in a hostile international environment. It certainly ruled out the formation of factions and other political groupings, the central 
accusation levelled against Trotsky and his supporters. And while Trotsky outright rejected this characterisation, his endorsements of the nature of foreign threats and the principle of unity in the party when war threatened, boxed him into a corner. These same concerns emerged again in the late 1920s when another war scare erupted and the opposition once more found themselves with little room for manoeuvre.

\section{The Piłsudski Coup and the War Scare}

In the mid-to-late 1920s, Soviet leaders were again preoccupied by the threat of war and ordinary people were just as concerned. In 1927 a war scare erupted across the Soviet Union, sparking outbreaks of hoarding and panic buying. The war scare in 1927 has sometimes been presented in the literature as manufactured by the Soviet leadership and designed as a tool to put pressure on the political opposition.$^{56}$ However, as we have seen, there is little to suggest that fears of war emanated solely from above or were designed instrumentally. Soviet intelligence reports from the ground level about a new conflict were unremitting in the early 1920s. Moreover, it was not just the party elite, but Commissariats of Defense and Foreign affairs, military intelligence and the political police, which discussed the likelihood of war in the near future. There was a shared understanding about the Soviet Union’s precarious position in the world and one shaped by a long-held and ideologically-informed understanding of international affairs. As we will see, key members of the opposition continued to be some, if not the most ardent, supporters of this worldview. 
The roots of the 1927 war scare can be found in the still tense relations between the Soviet Union and Poland. The country was the subject of increasing anxiety among Soviet leaders in 1926 and, in March, the Polish Commission of the Politburo ordered more attention given to Polish affairs. ${ }^{57}$ Rumours of Piłsudski’s return to power had started to circle, particularly following the fall of Aleksander Skrzyński’s government in May. As far as the Bolsheviks were concerned, this would greatly escalate the danger of war. The leadership also believed that Piłsudski’s return would shift the balance of geopolitical power and push Poland more closely towards Britain's orbit. ${ }^{58}$ OGPU leaders, Genrikh Iagoda and Artur Artuzov, stressed the danger shortly after Piłsudski’s return to power in mid-May and pointed to examples of recent aggressive British behaviour towards the Soviet Union, particularly in terms of trade restrictions and supposedly large-scale intelligence operations. The assumption was that Piłsudski’s return to power was through British design. Notably, Iagoda and Artuzov described Piłsudski as the 'guard dog' of the British in Eastern Europe and argued that he would try once more to forge a Polish federation with Ukraine and Belorussia. In response, the OGPU was to strengthen countermeasures against espionage and to keep a close eye on Polish affairs. ${ }^{59}$

Piłsudski’s coup d’état in May was anticipated, but it made the threat of war more pressing for the Soviet leadership. ${ }^{60}$ Piłsudski had already invaded once before during the SovietPolish War and had pushed interventionist stances while sat on the sidelines of Polish politics. After the May coup, preventing Polish aggression assumed a greater priority. The People’s Commissariat of Foreign Affairs recommended that Poland be isolated from its neighbours to prevent the formation of an anti-Soviet coalition. ${ }^{61}$ Red Army leaders, who had lobbied for higher levels of investment since 1924 on the grounds that Soviet defences could not withstand invasion from a coalition of states led by Poland, sounded the alarm again in 
summer 1926. The Soviet Defence Commission subsequently agreed to take ‘urgent measures for strengthening the defense potential of the USSR' ${ }^{62}$ Tukhachevskii was once again sent to the western front (this time to Minsk) and Aleksandr Egorov to Kharkov. ${ }^{63}$ Some regarded the situation as highly dangerous. Before his death in July, Dzerzhinskii vehemently argued that Piłsudski would now try to seize Belorussia and Ukraine, a warning he relayed personally to Stalin. ${ }^{64}$ On the ground in Ukraine, GPU agents reported on the renewed hope among separatists that Soviet defeat at the hands of Poland would bring about their independence. ${ }^{65}$

Not all were as alarmist as Dzerzhinskii, but even more measured appraisals of Soviet-Polish relations emphasised the dangerous environment after Piłsudski’s return to power. People’s Commissar for Foreign Affairs, Chicherin, was gloomy about the recent turn of events, writing to the OGPU head that Poland was trying to conclude agreements with the Baltic States, forcing the threat from Poland to be taken seriously. ${ }^{66}$ Soviet military intelligence forecast growing Polish militarism - and with it the threat of war - but its agents believed that the Soviet Union was safe from attack until at least spring $1927 .{ }^{67}$ The situation was bad, but it was not yet a crisis. Military intelligence rightly estimated that Poland required external assistance to build its military strength. Ultimately, however, should Poland be ready and pressured into war by Britain, it would represent a serious adversary. ${ }^{68}$

As to how Stalin judged the threat of war in the late 1920s, in public he sided with the view of military intelligence rather than with the alarmist Dzerzhinskii. In his speech to the Fifteenth Party Conference in November 1926, Stalin proclaimed that whether capitalist states were in a position to attack was still to be seen, but regardless, the Soviet Union 
remained in a position of encirclement. This was not a moment of respite and war could not be ruled out. ${ }^{69}$ It is possible that Stalin downplayed the threat for the benefit of the conference. Indeed, a few months later in February 1927, Maksim Litvinov suggested to Stalin that there was no reliable information that Britain was pushing Poland towards war. Stalin raked him over the coals and spoke about the existence of an international conspiracy against the Soviet Union and the inevitability of war. ${ }^{70}$ Stalin's close allies were evidently in agreement. In mid-1927, Lazar Kaganovich accused Piłsudski of waging a war against Moscow to seize Ukraine and claimed that Polish fascism was backed by 'foreign imperialism'. ${ }^{71}$

Stalin's appraisal of the nature of the Polish threat is also revealed in his reaction to the murder of Petr Voikov, the Soviet plenipotentiary in Poland, by a White monarchist in June 1927. In a telegram sent to Viacheslav Molotov immediately after Voikov’s death, and relying on his gut instincts, Stalin wrote that he 'felt the hand of England' behind Voikov's murder and suggested that the British government wanted to provoke war between Poland and the Soviet Union, repeating 'Sarajevo' ${ }^{72}$ The allusion to the assassination of Franz Ferdinand is suggestive of the danger that Stalin saw in Piłsudski’s Poland under British influence. The British government had already severed diplomatic relations with the Soviet Union one month before, following raids on the Soviet trade delegation and All-Russian Cooperative Society in London that the British authorities believed were fronts for Soviet intelligence. $^{73}$

Yet despite seeing a British conspiracy to wage war, Stalin still did not judge this as imminent in 1926 or 1927. Writing in Pravda in July 1927, Stalin accused the British 
government of preparing war against the Soviet Union but argued that this had been forestalled for two reasons: the peaceful policies carried out by the Soviet Union and the reluctance of countries such as Poland to 'serve as dumb tools of the [British] Conservatives to the detriment of their own interests.' Even so, Stalin claimed that capitalist powers would not stop in trying to provoke war and the immediate task facing the Soviet Union was to improve its economic power and military strength. ${ }^{74}$

\section{Renewed Pressure on the Opposition}

Heightened concerns about war against Piłsudski’s Poland and its capitalist backers placed more pressure on the political opposition at the height of its activity. Concerns about war continued to circumscribe open party discussion as had been true in previous years and created new concerns about the opposition undermining state defence. Dzerzhinskii saw internal disputes in the party as dangerous with Piłsudski back in power. In July 1926, he claimed that Piłsudski would detect weakness in the Soviet state because of the activity of the opposition. ${ }^{75}$ While Stalin was not as adamant as Dzerzhinskii about the imminence of war, he conveyed similar messages regarding the continuing dangers posed by factionalism. At the Seventh Enlarged Plenum of the Executive Committee of the Communist International (ECCI) in December 1926, he argued that a ‘united party armed with iron discipline’ was essential when imperialism was such a strong force in the world. In this context, attempts to undermine party unity or create a new party had to be 'rooted out'. In May 1927, again at a

plenum of the ECCI, Stalin referred to a 'united front from Chamberlain to Trotsky. ${ }^{\text {,76 }}$ Stalin followed this up in a Pravda article from July 1927 containing another scathing attack on the opposition: 
What, after all this, should be said of our luckless opposition in connection with its latest attacks on our Party in face of the threat of a new war? What should be said of the fact that it, this opposition, has found the war threat an appropriate occasion to intensify its attacks on the Party? What is there creditable in the fact that, instead of rallying around the Party in face of the threat from without, it considers it appropriate to make use of the U.S.S.R.'s difficulties for new attacks on the Party? Can it be that the opposition is against the victory of the U.S.S.R. in the coming battles with imperialism, against increasing the defensive capacity of the Soviet Union, against strengthening our rear? ${ }^{77}$

One month later, in another speech, Stalin explicitly connected the internal and external threats to the Soviet Union:

Comrades, we are faced by two dangers: the danger of war, which has become the threat of war; and the danger of the degeneration of some of the links of our Party. In setting out to prepare for defence we must create iron discipline in our Party. Without such discipline defence is impossible. We must strengthen Party discipline, we must curb all those who are disorganising our Party. ${ }^{78}$

Other senior Bolsheviks shared this view and likewise argued that the opposition was undermining Soviet defence and even threatened to stab the country in the back during war. ${ }^{79}$

Trotsky denied this volley of accusations and argued on the contrary that the opposition was the only group capable of steering the country through tense international times. Other 
members of the opposition lower down the chain took the same view and saw their programme as necessary for successful navigation of the international environment, especially curbing the influence of kulaks, as not doing so risked creating an internal front during war. ${ }^{80}$ As part of his defence, Trotsky provocatively made reference to Georges Clémenceau who had remained in opposition to French government during World War I until there was opportunity to take the leadership. After a backlash, Trotsky clarified his position in September 1927, arguing that his comments had been distorted and rejected the accusation that the opposition threatened to take power 'after the Clémenceau manner'. Yet at the same time, he again accepted the need for unity when war threatened: 'The dictatorship of the proletariat in a country which is surrounded by capitalist states does not allow either the existence of two parties or the factional splitting of a unified party.' For Trotsky, the problem remained the party elite's circumscribing of open discussion and its unaccountability. For him, the threat of war had no bearing on this: 'It is a lie that the danger or even war itself excludes the self-action of the party, which discusses and decides all questions and which directs and checks all its organs from top to bottom. ${ }^{91}$

In making this case, Trotsky faced exactly the same problem as in 1923 . He continued to agree that the Soviet Union would be endangered if the party split into factions and that unity was required in the face of war with the capitalist world. On the latter danger, Trotsky was unequivocal in 1927, writing to the Central Committee in June that the threat of intervention was 'unquestionable'. ${ }^{82}$ Moreover, in the Platform of the United Opposition, produced in 1927, he argued:

Another task of equal importance is to consolidate the ranks of our party, to put an end to the open speculation of the imperialist bourgeoisie and the leaders of 
Social Democracy on a split [...] All the organs of the international bourgeoisie and the Social Democrats are now showing a quite unusual interest in our innerparty disputes. They are openly encouraging and spurring on the present majority of the Central Committee to exclude the Opposition from the leading organs of the party, and if possible from the party [...] Moreover, we can buy ourselves off from a war, if that is possible - and conquer in the war, if we have to fight - only if we preserve complete unity; if we disappoint the hopes of the imperialists for a split or an amputation. Such a thing would benefit only the capitalists. ${ }^{83}$

For Trotsky, party unity would be damaged and the Soviet Union endangered if the opposition was expelled. The party majority saw the exact opposite. Indeed, Trotsky’s conception of party unity meant 'above all maximum active participation by the entire mass of the party. ${ }^{84}$ The majority saw this as unacceptable considering the international threats facing the Soviet Union. Even to allow more open discussion was regarded as potentially dangerous. The nature of political participation was thus the crux of the dispute and positions were irreconcilable. However, there was one crucial point of agreement. Trotsky fatally undermined his position by accepting the need for unity when war was on the horizon. In fact the danger posed by the outside world had not been seriously disputed since 1917 . The controversy was in how the party should respond and what exactly constituted 'unity'. And there was no chance that the party leadership would liberalise democratic practices when it judged the threat of war as acute. Critically, Trotsky did nothing to dispel this worldview. The conclusion therefore should not be that the party majority used the war threat instrumentally to crush internal critics. That Stalin wanted Trotsky out of the way was no secret, but as we have seen, the party, the opposition (and wider population in 1927) were convinced that it would not be long until the Soviet Union was at war. This was a long- 
standing conviction within Bolshevik circles that stemmed from their understanding of the international circumstances of the revolution. As far as the Bolsheviks were concerned, reams of intelligence, the evidence of hostile action foreign governments and war scares in the 1920s supported this worldview. If anything, Trotsky’s firm endorsement of future war only further cemented an authoritarian response to the challenges posed by the outside world and with it the maintenance of a one-party vanguard dictatorship with diminishing democratic standards.

Following Trotsky's expulsion from the Soviet Union, the international situation worsened in a very real sense in the 1930s. The response from the Soviet leadership was the further sharpening of the dictatorship and an increasing use of political violence. All the while, Trotsky remained a thorn in the regime's side from exile. His continuing opposition from abroad in turn became integral to the conspiracy theories that underpinned the Great Terror, themselves inseparable from the threat of war. 
${ }^{1}$ See for instance Oleg Khlevniuk, 'The objectives of the great terror, 1937-1938', in J. Cooper et al. (eds) Soviet History, 1917-53. Essays in Honour of R. W. Davies (Basingstoke, 1995); Peter Whitewood, The Red Army and the Great Terror: Stalin's Purge of the Soviet Military (Kansas, 2015); James Harris, The Great Fear: Stalin's Terror of the 1930s (Oxford, 2016).

${ }^{2}$ For an exception, Olga Velikanova examined the importance of the foreign threat to the Soviet Union in the 1920s and the impact of popular mobilisation campaigns. See Popular Perceptions of Soviet Politics in the 1920s:

Disenchantment of the Dreamers (Basingstoke, 2013).

${ }^{3}$ V. I. Lenin, Collected works, vol. 32 (Moscow, 1973), pp. 436, 454, 478.

${ }^{4}$ See Józef Borzęcki, The Soviet-Polish Peace of 1921 and the Creation of Interwar Europe (New Haven, 2008).

${ }^{5}$ Jan Jacek Bruski, Between Prometheism and Realpolitik. Poland and Soviet Ukraine, 1921-1926 (Krakow, 2016$), \mathrm{p}$. 13.

${ }^{6}$ Lenin, Collected works, vol. 32, pp. 114-15.

${ }^{7}$ A. A. Plekhanov and A. M. Plekhanov (eds), F. E. Dzerzhinskii-Predsedatel' VChK-OGPU, 1917-1926. Dokumenty (Moscow, 2007), pp. 248-9.

${ }^{8}$ Tsentral’nyi derzhavnyi arkhiv vyshchykh orhaniv vlady ta upravlinnia Ukraïny (hereafter TsDAVO), f. 4, op. 1, d. 14, 1. 23.

${ }^{9}$ Arkhiv Vneshnei Politiki Rossiiskoi Federatsii (hereafter AVPRF), f. 4, op. 32, p. 210, d. 52511, ll. $13-17$.

${ }^{10}$ Quoted in Michael Carley, Silent Conflict: A Hidden History of Early Soviet-Western Relations (Maryland, 2014), p. 55; Harris, Great Fear, p. 43, fn. 14.

${ }^{11}$ Rossiiskii gosudarstvennyi voennyi arkhiv (hereafter RGVA), f. 33987, op. 1, d. 460, 1l. 54-55.

${ }^{12}$ David R. Stone, 'The prospect of war? Lev Trotskii, the Soviet army, and the German revolution in 1923', The International History Review 25/4 (2003), p. 815.

${ }^{13}$ See Dzerzhinskii's letter to V. N. Mantsev, 11 November 1921. Plekhanov and Plekhanov, Dzerzhinskii, p. 344-5.

${ }^{14}$ See note to Konstanty Skirmunt, TsDAVO, f. 4, op. 1, d. 31, l. 3. See also Dokumenty vneshnei politiki SSSR, vol. 5 (Moscow, 1961), pp. 145-7.

${ }^{15}$ Odinnadtsatyi s'ezd RKP(b): Protokoly (Moscow, 1936), p. 637.

${ }^{16}$ Rossiiskii gosudarstvennyi arkhiv sotsial'no-politicheskoi istorii (hereafter RGASPI), f. 558, op. 1, d. $2326,1.1$.

${ }^{17}$ M. Ul', V. Khaustov and V. Zakharov (eds), Glazami razvedki. SSSR i Evropa, 1919-1938 gody: sbornik dokumentov iz rossiiskikh arkhivov (Moscow, 2015), p. 58.

${ }^{18}$ Ibid., p. 64. On the movement of Polish troops reported in July 1922, see RGVA, f. 25899, op. 3, d. 515, l. 118ob.

${ }^{19} \mathrm{Ul}$, Khaustov and Zakharov, Glazami razvedki, p. 83.

${ }^{20}$ TsDAVO, f. 4, op. 1, d. 591, 1. 2. Oleksandr Shumskyi, Soviet Ukraine’s Ambassador to Poland, also sent a warning to Frunze in September about Polish 'systematic preparations' for war. See Bruski, Prometheism and Realpolitik, p. 194 (fn. 11).

${ }^{21}$ RGVA, f. 25899, op. 3, d. 536, l. 1.

${ }^{22}$ On the Bolsheviks' enthusiasm for the revolutionary events in Germany, see Stone, 'Prospect of war'.

${ }^{23}$ RGASPI, f. 558, op. 11, d. 789, 1. 2.

${ }^{24}$ Stone, 'Prospect of war', p. 802.

${ }^{25}$ Dvenadtsatyi s'ezd RKP(b): stenograficheskii otchet (Moscow, 1968), p. 16.

${ }^{26}$ See intelligence report from January 1923, RGVA, f. 33988, op. 2, d. 533, 1. 3.

${ }^{27}$ RGVA, f. 25899, d. 3, d. 565, l. 120; Ul', Khaustov and Zakharov, Glazami razvedki, p. 108. Some intelligence presented a more moderate picture, noting that Foch believed that Poland and France should pressure the Bolshevik government into collapse, however, not going as far as armed intervention. RGVA, f. 33988, op. 2, d. 533, l. 89. ${ }^{28}$ RGVA, f. 25899, op. 3, d. 536, l. 34ob.

${ }^{29}$ Derzhavnyi haluzevyi arkhiv sluzhby bezpeky Ukraïny (hereafter DHASBU), f. 13, ark. 162, tm. 12, ll. 34.

${ }^{30}$ RGVA, f. 25899, op. 3, d. 536, 1. 30.

${ }^{31}$ RGVA, f. 25899, op. 2, d. 556, l. 206.

${ }^{32}$ RGASPI, f. 76, op. 2, d. 17, 1. 86.

${ }^{33}$ Plekhanov and Plekhanov, Dzerzhinskii, pp. 486-7.

${ }^{34}$ In a report to the Politburo two years later Frunze described this as a 'sudden transition' towards military preparations. N. S. Simonov, 'Strengthen the defence of the land of the Soviets': the 1927 'war alarm' and its consequences’, Europe-Asia Studies 48/8 (1996), pp. 1359-60.

${ }^{35}$ RGASPI, f. 17, op. 162, d. 1, l. 12.

${ }^{36}$ Stone, 'Prospect of war', p. 804.

${ }^{37}$ Ibid.

${ }^{38}$ TsDAVO, f. 2, op. 2, d. 905, 1. 8.

${ }^{39}$ RGASPI, f. 17, op. 87, d. 177, l. 95.

${ }^{40}$ DHASBU, f. 13, ark. 162, tm. 7, l. 2.

${ }^{41}$ RGVA, f. 308, op. 3, d. 39, 1. 25.

${ }^{42}$ On Polish politics in 1923, see Bruski, Prometheism and Realpolitik, pp. 73-4.

${ }^{43}$ Simon Pirani, The Russian Revolution in Retreat, 1920-24: Soviet Workers and the New Communist Elite (London, 2008), pp. 55-7. 
${ }^{44}$ Lenin, Collected works, vol. 32, p. 53. At a speech to Moscow metal workers shortly after, Lenin argued that dictatorship was necessary because the entire bourgeois world was against Russia. See ibid., p. 108.

${ }^{45}$ Ibid., pp. 167-9.

${ }^{46}$ Ibid., p. 495.

${ }^{47}$ Ibid., p. 505.

${ }^{48}$ Lenin, Collected works, vol. 33 (Moscow, 1973), pp. 322-4.

${ }^{49}$ Odinnadtsatyi s'ezd RKP(b), p. 138.

${ }^{50}$ Ibid., p. 603.

${ }^{51}$ Dvenadtsatyi s'ezd RKP(b), p. 6.

${ }^{52}$ Ibid., pp. 198-200.

${ }^{53}$ Valentina Vilkova, RKP(b). Vnutripartiinaia bor'ba v dvadtsatye gody. Dokumenty i materialy. 1923 (Moscow, 2004), p. 267.

${ }^{54}$ On the discussion about party democracy after October 1923, see Robert V. Daniels, The Conscience of the Revolution: Communist Opposition in Soviet Russia (New York, 1969), pp. 220-35. See also James Harris, 'Discipline vs democracy: the 1923 party controversy' in this volume.

${ }^{55}$ I. V. Stalin, Collected works, vol. 6 (Moscow, 1953), p. 23.

${ }^{56}$ See for instance, Boris Souvarine, Stalin: a Critical Survey of Bolshevism (New York, 1939); Daniels, Conscience of the Revolution; Ulam, Stalin: The Man and his Era (New York, 1979); David R. Stone, Hammer and Rifle: the Militarization of the Soviet Union, 1926-1933 (Kansas, 2000).

${ }^{57}$ RGASPI, f. 76, op. 2, d. 58, 1. 3.

${ }^{58}$ Iu. V. Ivanov, Ocherki istorii rossiisko(sovetsko)-pol'shikh otnoshenii v dokumentakh. 1914-1945 (Moscow, 2014 ), pp. 154, 160.

${ }^{59}$ DHASBU, f. 13, arkh. 445, 1. 1.

${ }^{60}$ A meeting of leaders from the political police, foreign ministry and military noted that the threat of war had significantly increased with Piłsudski’s return to power. RGASPI, f. 76, op. 3, f. 364, 1. 72.

${ }^{61}$ Ivanov, Ocherki, p. 151.

${ }^{62}$ Stone, Hammer and Rifle, pp. 20-22.

${ }^{63}$ Stephen Kotkin, Stalin: Paradoxes of Power (New York, 2015), p. 589.

${ }^{64}$ RGASPI, f. 76, op. 3, d. 364, 1.57; f. 558, op. 11, d. 726, ll. 55-56ob.

65 Iu. Shapoval, V. Prystaiko, and V. Zolotar'ov (eds), ChK-GPU-NKVD v Ukraïni: Osoby, fakty, dokumenty (Kyiv, 1997), p. 254.

${ }^{66}$ RGASPI, f. 76, op. 3, d. 364, 1. 71.

${ }^{67}$ A military intelligence report from June 1926 argued that Piłsudski would break with the efforts of his predecessors to improve relations with the Soviet Union. See Ivanov, Ocherki, p. 153.

${ }^{68}$ RGASPI, f. 76, op. 2, d. 58, 1. 156, l. 158.

${ }^{69}$ Stalin, Collected works, vol. 8 (Moscow, 1954), pp. $276-7$.

${ }^{70}$ Carley, Silent Conflict, p. 257; Kotkin, Paradoxes, pp. 623. Litvinov conveyed a similar message in January 1927 at a meeting of the foreign affairs commissariat. Here he argued that some intelligence reports were fantasy and that it was a mistake to see the malevolent hand of the British government everywhere. Ibid., p. 622.

${ }^{71}$ L. S. Gatagova, L. P. Kosheleva and L. A. Rogovaia (eds), TsK RKP(b) - BKP(b) i natsional'nyi vopros, kniga 1 1918-1933 gg. (Moscow, 2005), pp. 486-93.

72 RGASPI, f. 558, op. 11, d. 71, 1. 2.

${ }^{73}$ In a speech following the raids in London, Voroshilov claimed that the next logical step was a British attack on the Soviet Union. RGASPI, f. 74, op. 2, d. 49, 1. 42.

${ }^{74}$ Stalin, Works, vol. 9 (Moscow, 1954), pp. 328-69.

${ }^{75}$ RGASPI, f. 558, op. 22, d. 726, 1l. 55-56ob. Dzerzhinskii was not totally off the mark. The Polish press reported on the ongoing internal struggle and the inability of the party majority to do anything about this. See Gosudarstvennyi arkhiv Rossiiskoi Federatsii, f. 4459, op. 2, d. 158, 1. 45.

${ }^{76}$ Stalin, Works, vol. 9, p. 318.

${ }^{77}$ Ibid, pp. 336-7.

${ }^{78}$ Stalin, Works, vol. 10 (Moscow, 1954), p. 62.

${ }^{79}$ See Voroshilov's and Arkady Rosengolts's comments in 1927: RGASPI, f. 74, op. 2, d. 49, 1l. 47, 77.

${ }^{80}$ Igal Halfin, Intimate Enemies: Demonizing the Bolshevik Opposition, 1918-1928 (Pittsburgh, 2007), p. 246.

${ }^{81}$ Leon Trotsky, 'The “Clémenceau thesis” and the party regime', September 1927. Available at https://www.marxists.org/archive/trotsky/1927/09/clemenceau.htm.

${ }^{82}$ Trotsky, The Challenge of the Left Opposition 1926-27 (New York, 1980), p. 245. Zinoviev was just as adamant about the inevitability of war. See Simonov, 'Strengthen the defence', p. 1359.

${ }^{83}$ Trotsky, 'Platform of the joint opposition', 1927. Available at https://www.marxists.org/archive/trotsky/1927/opposition/ch09.htm.

${ }^{84}$ Trotsky, The Challenge, p. 248. 